\title{
Introduction to the Research Handbook on Corporate Bankruptcy Law Barry E. Adler
}

More than thirty years ago, Thomas Jackson wrote The Logic and Limits of Bankruptcy Law, which describes bankruptcy as the implementation of a hypothetical bargain among creditors. Under the terms of such a bargain, bankruptcy's automatic stay on each creditor's individual collection rights prohibits a potentially destructive grab race and allows for a collectivized proceeding that can maintain a debtor's going-concern value for the benefits of the creditors as a group. Among both academics and practitioners, Jackson's hypothetical bargain has become the dominant paradigm in assessing bankruptcy, a true feat for a scholarly work.

Much has changed since Jackson wrote his classic treatise, particularly in the world of large-firm corporate bankruptcy, which is the primary focus of this handbook. Creditors have taken control of the corporate reorganization process, previously the domain of debtor management (the "debtor in possession" or "DIP"). Creditor control has been solidified over time by an expanded use of secured credit and prebankruptcy contractual arrangements that allow principal creditors to speak with a single voice in the bankruptcy process.

To the extent honored by the bankruptcy courts, such coordination among principal creditors largely replaces Jackson's hypothetical creditors' bargain with an actual bargain. That actual bargain has important consequences for the bankruptcy process including a financial stranglehold that restricts a bankruptcy court's ability to have the process fully honor the entitlement of creditors not part of the coalition. Full adherence to entitlement-known in some contexts as "absolute priority"- has, thus, become difficult to achieve for new reasons. Now, it is dominant creditors who may manage bankruptcy for their own advantage while in the past it was the debtor's shareholders who, despite holding options that were out of the money, had their managers run the bankruptcy process toward achieving some return to equity.

Another consequence of principal creditor coordination in bankruptcy is that large-firm debtors are today, more than in the past, sold in bankruptcy. Fewer firms now undergo traditional reorganization, with new claims and interests issued against the debtor's assets. In principle, this 
trend toward market resolution of financial distress can cure valuation problems that plagued traditional reorganization. But control of the process still matters because the sale of a large, complex company, such as automakers, for example, are not as simple as depicted on a law professor's chalk board (or PowerPoint slide). The auction process - how assets are marketed and to whom - can determine winners and losers and so there is a new front in the bankruptcy battles, one not typically fought back when Jackson first wrote on the topic.

More than just bankruptcy practice has changed; the economy has changed as well in ways that affect corporate bankruptcy. Large corporations have become increasingly global, rendering more important the international coordination of bankruptcy laws.

Also, as we learned painfully more than a decade ago, enormous financial institutions such as bank holding companies have become too big safely to fail and yet vulnerable to failure. This dangerous circumstance prompted Congress to pass the Dodd-Frank Act, which both regulates systemically important financial institutions ("SIFIs") and provides for their demise, including through bankruptcy. Such regulation, considered onerous by some, and the systemic consequences of bankruptcy for such debtors has prompted proposed deregulation in the Financial Choice Act and a proposed special chapter of the Bankruptcy Code for SIFIs in the Financial Institutions Bankruptcy Act. Although Congress enacted modest revision in 2018, an overhaul of Dodd-Frank is currently in limbo at least until the 2020 federal elections. Any such overhaul could have dramatic consequences for the failure of large financial institutions.

A related change in recent years is the burgeoning market for derivatives, which can be described, though not entirely accurately, as bets on the future value of securities and commodities. As financial, and other, large firms heavily issue or invest in these derivatives, exposure to market changes becomes acute, enhancing the risk and suddenness of collapse beyond what could have been imagined years ago when financial firms more simply transformed maturity while industrial firms were seen more simply as manufacturers and sellers of goods and services. Bankruptcy law has changed to account for the growth of derivatives but it's not clear the change has been for the better.

The chapters of this handbook touch on all these changes, as well as on other matters. That said, the chapters are not fundamentally chronologies or histories. Where relevant, each chapter provides the reader with a comparison between its topic today and in the past. But most of the chapters are centrally current analyses of their topics. Through the use of past as prologue, this volume is intended to be, in part, an update to the Jacksonian paradigm, which, while still relevant, has changed with the times. 
In the book's Chapter 1, Bankruptcy Logic and Limits in the 21st Century: Some Thoughts on Chapter 11's Evolution and Future, Tom Jackson traces the past and predicted future of corporate bankruptcy, addressing many of the issues already discussed in this Introduction, including the application of the creditors' bargain model to systemically important financial institutions. The content of this chapter, which was drafted prior to the recent legislative developments mentioned above, has already proven influential.

Next, Chapter 2, Robert Rasmussen's The End of Bankruptcy Revisited also traces the history of corporate bankruptcy, emphasizing the shift from a debtor-driven reorganization process to a creditor-driven auction block. In this chapter, Rasmussen updates an influential series of articles he wrote on the topic with Douglas Baird, a long-time co-author of Rasmussen (and, separately, of Jackson).

In Chapter 3, Bankruptcy Sales, Melissa Jacoby and Ted Janger take on the much-debated issue of whether auctions in the practice of modern corporate bankruptcy are properly structured to maximize the debtor's value and to honor absolute priority among a debtor's claims and interests. The authors suggest that the current system is less than ideal but possible to reform.

Chapter 4 is David Skeel's The New Synthesis of Bank Regulation and Bankruptcy in the Dodd-Frank Era. This chapter, the title of which is largely self-explanatory, expands on Jackson's original insights and explores the perhaps vanishing distinctions between the resolution of bank and industrial firm financial distress.

In Chapter 5, Derivatives and Repos in Bankruptcy, Mark Roe explores the brave new world of bankrupt debtors, potentially including bank debtors, and their network of counterparties, saddled by obligations on derivatives. Among other matters, Roe speculates that the Bankruptcy Code's treatment of derivatives has been in approach exactly backwards.

Chapter 6, Richard Squire's Distress-Triggered Liabilities and the Agency-Cost of Debt, continues with the derivatives' theme and explains how investors in these instruments can manipulate risk to gain advantage over others in a firm's insolvency. Squire describes how the prospect of such strategic behavior creates perverse incentives.

The next two chapters address the modern fundamentals of what might be described as durational bankruptcy issues. Were the corporate bankruptcy process to begin and end in the same instant, no special rules would be required for the management and finance of the debtor during the bankruptcy process and this would be so whether the process reorganized a debtor's capital structure or sold its assets and distributed the proceeds. In fact, however, bankruptcy takes time. To preserve a debtor's potential 
going-concern value for the duration of the process, assets may need protection from piecemeal liquidation by creditor collection. (This is, as noted, central to Jackson's hypothetical bargain among creditors.) And the business of the debtor must be financed (referred to as "DIP" finance) so that the debtor can continue until disposition.

In Chapter 7, On the Mandatory Stay of Secured Creditors in Bankruptcy, Kenneth Ayotte newly considers, and critiques, the merits of bankruptcy's automatic stay as protection against a creditor grab race. In Chapter 8, Debtor-in-Possession Financing in Bankruptcy, George Triantis updates his own pioneering work on DIP finance, which is carefully assessed on efficiency terms.

Continuing the theme of efficiency, the following two chapters summarize and enter a debate on what may be the central question brought to the fore by recent changes, and proposed changes, in the bankruptcy process, namely: Should corporate bankruptcy honor traditional notions of absolute priority? In Chapter 9, Anthony Casey and Ed Morrison's Beyond Options, and in Chapter 10, Michelle J. White's The Treatment of Secured Credit in Bankruptcy, the authors respectively explain why they believe the traditional answer of simply "yes" is insufficiently nuanced.

Chapter 11, Michael Simkowic's Making Fraudulent Conveyance Law More Predictable, also addresses absolute priority, but in the indirect context of fraudulent conveyance laws, which along with related rules on voidable preferences, importantly determine priority in fact. In this chapter, Simkovic takes a new look at these rules.

The next chapters address an important current controversy on the direct and indirect costs of the bankruptcy process. In Chapter 12, The Costs of Corporate Bankruptcy: How Little We Know, Stephen Lubben summarizes and assesses the current evidence on the direct costs of corporate bankruptcy proceedings, while in Chapter 13, The Chrysler and General Motors Bankruptcies, Todd Zywicki uses the U.S. automaker cases to illustrate what he views as a costly manipulation of the bankruptcy process (including indirect costs as a result of deviations from absolute priority).

Chapter 14, John Pottow's Cross-Border Corporate Insolvency in the Era of Soft (ish) Law, shifts focus from exclusively U.S. bankruptcy cases to cross-border cases. In this chapter, Pottow takes account of increasing globalization to update a longstanding debate between universalists and territorialists on choice-of-law. Since this chapter was drafted, the United Nations Commission on International Trade Law ("UNCITRAL") has supplemented its Model Law on Cross-border Insolvency, discussed in the chapter, with The Model Law on the Recognition and Enforcement of Insolvency-related Judgments. The supplement is consistent with, and 
evinces the insights of, the approach to cross-border insolvency described in the chapter.

The final chapter of the book is a thought experiment by a leading bankruptcy theorist. In Chapter 15, Bankruptcy Related Contracting and Bankruptcy Functions, Alan Schwartz compares statutory rule to contractual alternatives and imagines how the world might change if the former were altered so that bankruptcy law addressed only those functions creditors need as determined by the capital structures that debtors adopt. This chapter questions the premises of the Jacksonian creditors' bargain and serves also as a rebuttal of sorts to earlier chapters that question the efficacy of absolute priority. The role of contract in bankruptcy is a topic to which Schwartz has importantly contributed in the past, but in this chapter he adds significant new observations. 